\title{
Factors Impacting Academic Writing Skills of English Second Language Students
}

\author{
Jack M. Chokwe \\ Department of English, University of South Africa \\ chokwmj@unisa.ac.za
}

\section{Doi:10.5901/mjss.2013.v4n14p377}

\begin{abstract}
The student writing difficulties cannot be attributed to one factor but a myriad of factors, including colonialism and apartheid, which were instrumental in the marginalisation of blacks in South Africa. The problems of underprepared teachers, ineffective teaching of writing in schools which also provided fewer writing activities and fewer opportunities for learning in a second, third and fourth language, are some of the factors discussed in this article. The article argues that drastic measures should be made to address the scourge of poor writing skills manifested in the writing of English Second Language students.
\end{abstract}

Keywords: academic writing, Academic Literacies Model, under-preparedness

\section{Introduction}

There are a number of factors that contribute to poor academic writing skills amongst first year university students. The article presents a critical review of literature on aspects leading to unsatisfactory writing abilities of English Second Language (ESL) students both from a local and international perspective. These factors include under-preparedness caused by ineffective teaching of writing at school level, socio-economic issues and inadequate reading. Consequently, these factors affect the quality of student writing at tertiary level. The article argues that these issues need to be addressed if ESL student writing is to be improved.

\section{Under-Preparedness in ESL Contexts}

The advent of democracy in South Africa made it possible for previously marginalised and disadvantaged people to access education. However, 19 years after the end of apartheid, many students are insufficiently prepared by the schooling system to succeed at higher education. This problem is not unique to South African context only, but other contexts as well. For instance, in the United States, society still struggles with translating gains of access to college into increases in college completion (Engstrom 2008:6). She argues that colleges serve a large number of working class and under-represented students. The fact that most of our learners are ESL seems to be a major contributing factor to the dismal performance of our students (Jacobs 2005:476).

Under-preparedness is caused by a number of factors. As Engstrom (2008:6) contends, students may be unprepared because of inadequate schooling experiences, competing family and work demands, lack of English language competency or unfamiliarity with how the college works. Furthermore, Sanchez and Paulson (2008) argue that minority students' underprepared status often serves to compound their marginalisation and oppression. As pointed out earlier, South African schools too are not unique to this phenomenon. It is a worldwide occurrence, particularly in ESL contexts where English is the medium of instruction. Similarly, other authors indicate that their students typically come from educationally underprepared backgrounds, with some having had no access to libraries and attempt some interventions to meet the demands of university reading and writing tasks (Granville and Dison 2009:56; Bharuthram and McKenna 2006:504; Schwartz 2004:27). The article argues that academic under-preparedness inevitably leads to academic exclusion as these students are likely to dropout due to lack of success in their studies. This may subsequently lead to withdrawal of funding by sponsors.

As Carhill, Suaréz-Orosco \& Puéz (2008:1156) report, low levels of academic English language proficiency can be an obstacle to academic success and to full participation in the discipline. Similarly, Hirst et al. (2004:66) argue that students were not equipped by their previous life experiences with the academic or tertiary literacies required of them. Furthermore, Maloney (2003:664) argues that these students are often portrayed as unable to manage rigorous academic tasks and as such are not fit for higher education studies. Similarly, Fregeau (1999:8) reports that students 
were admitted to different disciplines without having acquired the academic English writing skills they needed to succeed in those courses. However, Cliff and Hanslo (2009:266) observed that what students have learned at secondary school appears to make them better prepared to cope with the academic demands they face in higher education and also favourably associated with academic success and graduation. In contrast, some scholars, including the author of this article, reject this assertion as the opposite is the most common finding in ESL academic writing research (van Schalkwyk and van der Walt 2009; Bharuthram and McKenna 2006; Gambell 1991). Nevertheless, Cliff and Hanslo's (2009) assertion may apply to those students who attended well resourced schools, particularly private schools which are attended by children from affluent families.

Student under-preparedness tends to be perceived as a student problem. Several researchers argue that the problem of student writing is also exacerbated by teaching staff members who are at times under-qualified, underprepared and inefficient (Engstrom 2008:17; Moutlana 2007; Niven 2005). In addition, Engstrom (2008:17) contends that institutions that are serious about supporting the academic success and persistence of underprepared students must prepare the teachers, not just the students, about what these students need to learn and succeed. Engstrom (2008:6) further argues that many urban two- and four-year colleges are ill-prepared to deal with the substantial developmental needs students bring to the classroom. To address academic writing difficulties, lecturers or tutors should also see themselves as active participants in the process by making sure that they are fully equipped and trained to help students with academic writing. Engstrom (2008) is to be applauded for these brave remarks. Mostly, the authorities will only make a political rhetoric that does not produce any tangible action towards resolving this impasse.

From the schooling system to tertiary education, there are still instances where members of the teaching staff are not trained to teach the subjects they are teaching. For instance, lecturers or tutors may be highly qualified in a specific subject but may not have been trained to teach the course, or a lecturer or tutor may be required to teach a course that was never part of his or her training. In most cases in the education field, most of the blame is put on students (Luna 2002:602) and none on the teachers. Teachers should also reflect on their practice and be introspective about what might be right or wrong about the pedagogic practices and approaches that they employ in their classrooms. A new breed of such practitioners is needed in the educational circles for the better development of our students' academic writing. With the kind of background that our students come from, we seem to be expecting miracles from our students in producing quality academic work without proper training. Such expectations cannot be justified.

\section{Student Writing at School Level}

Schools play a critical role in developing students' reading and writing skills. If student writing is not addressed adequately at school level, the higher education sector will always be inundated with students who are academically under-prepared. Hart (1995:118) reports that such ESL learners seldom use English in their daily lives, and that crowded classrooms and poor facilities dominate their learning and teaching environment. He also projects that this situation will remain in the schooling context for the vast majority of South Africans for the foreseeable future.

Notably, it is clear that what students learn in high school either prepares or under-prepares them for university studies. Cliff and Hanslo (2009:267) also observed that students from under-resourced school backgrounds are often characterised by weak academic performance, and that this was likely to continue in higher education. In addition, Lea and Street (2006:369) argue that the Academic Literacies (AL) model might make explicit how teaching procedures are framed, not as deficit for students who are non-native speakers of English, but as something that all students encounter as they shift from secondary to tertiary education. In the same way, van Schalkwyk, and van der Walt (2009:192) argue that reading and writing play a fundamental role in student learning and their acquisition during the first year at university could be regarded as a critical factor in student success. More importantly, Scott (2006 in van Schalkwyk and van der Walt 2009:196) reports that under-prepared students may need further support before they achieve membership to the communities of practice in higher education.

Some researchers attribute students' poor writing skills to the teachers' reluctance to teach writing. For instance, Harris (1977:175) reports that some teachers do not teach composition at school level. This situation is exacerbated when students come to institutions of higher learning and are also confronted by academics who are not willing to teach academic writing (Moore 1998; Boughey 1997; Gambell 1991). Furthermore, research also indicates that there are fewer writing activities done in schools and student writing is underestimated (Wingate 2006; Cohen and Riel 1989). For example, Wingate (2006:458) found that many students are no longer required to write essays at secondary schools and that that could be why students have problems with academic writing.

In recent years, there have been numerous complaints about low literacy standards in schools. For instance, 
Nightingale (1988:265) mentions that the media attacked allegedly low educational standards which allow a generation of illiterates as a result of frequent attempts in tertiary institutions to set up some sort of fix-it programme to correct the problems left over from secondary education. Similarly, Munro (2003:327) states that dealing effectively with students' literacy difficulties is a challenge that faces many teachers and schools. This article concurs that indeed our students' writing skills demonstrate a dysfunctional education system that younger generations have to live with and that can be attributed to lack of quality leadership in education that should start addressing these issues.

Although most research on academic literacy and academic writing has been conducted in universities, Lea and Street (2006:368) argue that academic literacies also apply to K-12 education (Grades R-12). In their study, Lea and Street (2006:370) report on an Academic Literacy Development Programme (ALDP) which was sponsored by the British government to address the problem of under-prepared students. The programme, conducted by Kings College, London, targeted students in Grade 12 who were considering university study to prepare them for academic writing in a tertiary institution (Lea and Street 2006:370). In the ALDP, explicit attention was focused on switching, transformation and the changing of meanings and representations from one genre and mode to another, which are elements that were missing from their schooling (Lea and Street 2006:372). The author argues that South Africa should also learn from this model where the Department of Education should fund institutions of higher learning to carry out projects such as these to facilitate a smooth transition of secondary school learners into tertiary education.

Some writing deficiencies are attributed to lack of creativity in the classroom practices. Cohen and Riel (1989:156) report that the task of writing in schools was not effective and could have been effective when writing to an imaginary audience, and if the purpose was made explicit. Similarly, Engstrom (2008) reports that students consistently said that high school was a waste of time; they learned little from the lecture mode of class delivery and spent few hours (if at all) studying. In addition, Jurecic (2006:2) observed the perception gap that exists between professors and high school teachers and what they think students need to know to be prepared for college. As a result, Jurecic (2006:6) suggests a close collaboration between colleges and high schools in order to address writing issues. The article argues that the gap between high school and tertiary education should be narrowed and as long as the status quo remains, the state of our student writing and education in general will remain unchanged.

\section{Academic Writing at First Year Level}

Academic writing is the core skill that every university student should possess. Analogically, it can be compared to a currency of exchange in higher education where students need to produce written work in exchange for a grade eventually leading to graduation. Student writing and success in developing general communication skills through discipline-based modules is at the centre of teaching and learning in Higher Education (Jackson, Meyer and Parkinson 2006:261; North 2005; Ellis, Taylor \& Drury 2005, Krause 2001; Lillis 2001:20). On the other hand, writing and academic discourse are difficulties that many students encounter as they shift to higher education (Lea and Street 2006:370). Gambell (1991:421) reported that professors were not willing to teach students to write in the mode of discourse valued in the discipline. As Yong (2010:474) argues, the transition from secondary school to foundation studies poses a serious challenge for many in terms of academic writing. Understandably, lecturers are also frustrated and complain about their students' reading and writing deficiencies (Jackson et al. 2006:261; Moore 1998:88). Nevertheless, Ellis et al. (2005:54) investigated students' conceptions of writing, their approaches to writing and their perceptions of the learning context and found that, though challenging, the teaching of biology to first year university students can be integrated successfully with teaching writing. This suggests that writing can be taught more effectively in the relevant disciplines in which students are members in those communities of practice.

Academic writing should not be relegated to one department (English) or to Academic Literacies Centres but should be a joint effort of both language and discipline specialists. Researchers concur that the teaching of academic writing should involve collaboration between language specialists and discipline specialists (Elton 2010:152; Mitchell and Evison 2006:72; Jackson et al. 2006; Hawkins 2005:59; Jacobs 2005:475). In addition, Gee (1990 in Jacobs 2005:478) argues that people who have been allotted the job of teaching discourses are best placed to change the social structures at institutions that continue to marginalise non-mainstream students. On the other hand, Mitchell and Evison (2006:72) argue that the teaching of writing should not be a remedial or add-on activity, but an integral, on-going part of disciplinary learning for all students. They further argue that teaching writing should be part of the responsibility of disciplinary academics and should occur within the disciplines' curriculum (ibid). Lea (2004:741) observed, however, that it is common in higher education for the teaching of, or support for, student writing to be separated from mainstream study in learning support programmes or specialist foundation courses for undergraduates. She further argues that where all 
teaching and communication is in writing and where there is no face-to-face communication for participants, issues of literacy, language and learning are inevitably pertinent to the teaching and learning contexts (ibid).

Jurecic (2006:6) identified three essential points about college writing, namely: that students will be expected to write in all disciplines and a significant part of their grades may be based on their writing-papers and exams; college writing frequently requires students to write lengthy and challenging texts and that college writing generally involves making arguments, taking positions, and developing coherent intellectual projects. Significantly, all these authors agree that academic literacies should be taught within the disciplines by discipline specialists and not as a remedial activity by language specialists. Therefore, the foundation of academic writing should be laid by language specialists by teaching conventions of academic writing and be continued to be taught by discipline specialists so that students can be apprenticed and acculturated into the discourse communities they are entering. But, in many instances, students with academic writing problems are always referred elsewhere for assistance. The author argues that such perceptions should change and all academics regardless of their discipline should be involved in producing a product (student) that is competent to write even after graduation.

In a nutshell, academic writing remains a challenge in tertiary education. The AL approach may alleviate this problem as it advocates for the collaboration of language and discipline specialists. These two practitioners tend to operate in silos where language pedagogy is considered the sole responsibility of language specialists. Discipline specialists are also best suited to teach discipline specific discourse and should not just assume that ESL students will acquire academic literacy through immersion.

\section{Socio-Economic Factors}

Socio-economic factors contribute negatively to student learning, particularly to academic writing. In the United States, Sanchez and Paulson (2008:165) observed that students who are in transitional English courses often come from inferior schooling conditions. These observations by Sanchez and Paulson (2008) apply in the South African context where historically disadvantaged groups, in this case a majority, have had similar experiences. In addition, van Rensberg and Lamberti (2004:68) argue that it is widely understood that students who attended under-resourced rural and township schools are under-prepared and will have difficulty with writing at university.

Poor student writing cannot only be attributed to the poor schooling system but also to universities, because in South Africa, universities took up the role of Teacher Training after Colleges of Education closed down. Hence, academic staff from universities should take responsibility and also contribute in addressing students' academic writing problems. Though it will be a difficult exercise to embark on, higher education institutions should endeavour to correct what the schooling system failed to do by designing effective writing programmes that will catapult students into contextual academic discourses within their respective disciplines as well as effective teacher training. This study acknowledges that in order to address student writing difficulties, a holistic approach is needed and it has to start from elementary education through to higher education where writing intensively becomes an integral part of the learning outcomes. Academic staff should also get themselves involved in teaching and transferring academic writing skills to students because in some instances, specific discipline-related writing problems will require subject-specific interventions which language specialists do not have.

Many under-privileged students in South Africa now have access to higher education as opposed to the previous political dispensation where universities were only meant for the privileged few (van Rensberg and Lamberti 2004:67 \& Boughey 2000:281). In addition, van Rensberg and Lamberti (2004:67) argue that universities are no longer only for the elite. The same sentiments are also echoed by Boughey (2000:281) who states that in the past university education was reserved solely for the educated elite who had been equipped for the experience and taught in schools that prepared them for university studies and homes that did not differ from those of their lecturers and professors. She further states that now, with the massification of education, more doors are opening for students who never had such privileges (Boughey 2000:281). However, the opening of the doors of education to historically disadvantaged communities also brought challenges of reading and writing with it. Such students need to be supported, particularly in improving their academic writing competencies, so that they can function effectively within their discourse communities in universities. However, it is difficult to support these students when academics often disagree on what academic writing should entail and who should be responsible for teaching academic writing.

As shown above, socio-economic factors made a significant contribution to the kind of ESL students we currently have. The link between the disadvantaged backgrounds of ESL students and academic writing has been established, and directly impacts on learning, particularly writing. Although the AL approach is deemed to be appropriate in 
addressing student writing difficulties, socio-economic factors are out-of-school factors which the government should attempt to address. Therefore, interventions like school-feeding programmes should be continued and be extended to schools that are not yet on the programme. Moreover, schools should be provided with the infrastructure in order to make the environment conducive for learning.

\section{Writing as a Product of Reading}

Writing cannot be discussed in isolation from reading. Research has shown that the two complement each other (Rose 2004; Munro 2003). For example, Rose (2004:96) argues that parent-child reading before school is the first stage in a curriculum of reading skills that underlies the content and processes of teaching and learning in each stage of schooling. He found that parent-child reading is not practised in rural areas where the indigenous people of Australia live (Rose 2004:96). Similarly, Jubhari (2009:68) also reports that the aboriginal people of Australia only received basic reading and writing and are not fully functional in Australian society because they were not introduced to cultural values embedded in the use of the English language. This situation is comparable to a majority of South Africans who live in rural areas. In addition, Rose (2004:96) argues that writing activities in schools tend to be regarded as secondary and are dependent on reading proficiency. Furthermore, he suggests that for learners to become better writers, they have to master reading from an early age. The implication is that in order to have students who are adequately prepared for higher education in terms of academic writing, the whole schooling system from early childhood development to high school should be infused with systematic reading and writing activities and students will have a smooth synergistic transition to tertiary education (Munro 2003).

However, Jurecic (2006) argues that teaching writing in high school or college is challenging in this era where the reading culture has been eroded by television, movies, videos and games, amongst other factors. He maintains that students need to read more to be prepared for reading and writing in different disciplines (Jurecic 2006:10). He also suggests that students also need more practice in using writing to explore ideas, develop positions, deliberate about problems and paradoxes, make arguments and think new thoughts about the world (Jurecic 2006:11). Furthermore, Voss and Silfries (1996 in Maloney 2003:665) suggested that at-risk college students must first become fluent in academic literacy. Baker (1974 in Maloney 2003) found that 85\% of all learning in college comes from independent reading. These studies underscore the fact that reading and writing are indispensable skills that needed in all education levels. Learners without these basic skills have been robbed of fundamental education.

Kobayashi \& Rinnert (2002:97) indicate that reading is prevalent in Japanese high schools while writing is not given a primary role. Furthermore, Cabral and Tavares (2002:2) report that lecturers complain that students do not read analytically, cannot distinguish between important and unimportant ideas, cannot adjust their reading to the different materials they encounter and do not enjoy reading. In their qualitative study that used open-ended interviews for 80 students, Christison and Krankhe (1986:63) found that previous studies on students' beliefs and perceptions were flawed because of objectivity, sampling and validity. They report that students in their study preferred an active interactional approach to language learning (Christison and Krankhe 1986:73). They also found that listening and reading (80\%) dominated their language learning more than speaking and writing (20\%). In summary, research suggests a strong link between reading and writing, thus indicating that these academic literacies components are pivotal in academic writing.

Zamel (1992:463) states that writing allows students to write their way into reading, that reading shares much in common with writing, and that reading is also an act of composing. She critiques the way reading is being taught in schools. She observed that students view the purpose of reading as to answer questions that follow after reading. In agreement with Freire (1970), she also noticed that students read textbooks so that they can regurgitate what they read back to the teacher, and that if students fail to regurgitate information, they feel they are not good readers. She also noted that students are apprehensive about their own writing. Notably, Zamel (1992:468) challenges the structure of reading textbooks which relegates writing to the last activity. Therefore, reading and writing are reciprocal as students read what has been written and incorporate that as part of their writing. She also argues that writing enables us to re-look at texts in a way which lets us grapple with uncertainties, reflect on complexities, deal with puzzlements, and offer approximate readings. She also argues that writing dispels the notion that reading is a matter of getting something and getting it at the outset (Zamel 1992: 472).

The biggest challenge is that there is little synergy between what happens in high schools and what happens in tertiary education. The high school curriculum contributes very little to the tertiary education curriculum, particularly in the teaching of writing. This gap needs to be addressed so that ESL students from high schools can be better equipped for the writing demands required in higher education. Unless this problem is addressed, the problem of student writing 
difficulties will be perpetuated. Though important, the practice of focusing more attention on grammar in teaching language in high schools has not helped students improve their writing skills and more attention should be on writing longer texts where students are exposed to argumentation and other skills they will need in tertiary education.

\section{Conclusion}

In summary, this article discussed pertinent challenges that impact negatively on the teaching and learning of writing. These included the lack of proper teaching of reading and writing in schools, which creates a problem when students go to institutions of higher learning. Under-resourced schools and impoverished family backgrounds also have an effect on the poor state of ESL students' writing skills. The articles calls for strategic planning in education and successful education system in the world used tried and tested method for over 30 years. It is time to reflect and allow more time for debate as Phil Wood (2013) argues that we need to slow down the process of time.

\section{References}

Boughey, C.2000. Multiple metaphors in an understanding of academic literacy. Teachers and Teaching: theory and practice, Vol.6, No.3, pp. $279-290$.

Boughey, C. 1997. Learning to write by writing to learn: a group-work approach, ELT Journal, Vol. 51, No. 2, pp.126-134

Carhill, A., Suaréz-Orosco, C. \& Puéz, M. 2008: Explaining English Language Proficiency among Adolescent Immigrant Students, American Educational Research Journal, Vol. 45: No.4, pp. 1159-1179.

Christison, M. \& Krahnke, K.J. Student Perceptions of Academic Language Study, TESOL Quarterly, Vol. 20, No.1,pp. 61-81.

Cliff, A. and Hanslo, M., 2009.The design and use of alternate assessments of academic literacy as selection mechanisms in higher education. Southern African Linguistics and Applied Language Studies, Vol. 27, No. 3, pp. 265-276.

Cohen, M \& Riel, M. 1989: The Effect of Distant Audiences of Students' Writing, American Educational Research Journal, Vol. 26, No 2, pp. 143-159.

Ellis, R.A., Taylor, C.E. \& Drury , H. 2005. Evaluating writing instruction through an investigation of students' experiences of learning through writing, Instructional Science, Vol. 33, pp. 49-71.

Elton, L. 2010. Academic writing and tacit knowledge, Teaching in Higher Education, Vol.15, No. 2, pp. 151-160.

Engstrom, C.M. 2008. Curricular Learning Communities and Unprepared Students: How Faculty can Provide a Foundation for Success. New Directions for Teaching and Learning, No. 115, pp. 5-19.

Freire, P.1970. Pedagogy of the oppressed. England, Penguin Books.

Gambell, T.J.1991. University Students' Self-Perceptions of Writing. Canadian Journal of Education, Vol.16, No 4, pp.420-433.

Granville, S. and Dison, L., 2009. Making connections through reflection: writing and feedback in an academic literacy programme. Southern African Linguistics and Applied Language Studies, Vol. 27, No. 1, pp. 53-63.

Harris, W.H. 1977. Teacher Response to Student Writing: A Study of the Response Patterns of High School English Teachers to Determine the Basis for Teacher Judgement of Student Writing. Research in the Teaching of English, Vol.11, No.2, pp. 175-185.

Hawkins, M.R. 2005. Becoming a student: Identity work and Academic Literacies in Early Schooling, TESOL Quarterly, Vol. 39, No.1, pp. 59-82.

Hirst, E, Henderson, R, Alan, M, Bode, J and Kocatepe, 2004. Repositioning academic literacy: Charting the emergence of a community of practice. Australian Journal of Language and Literacy, Vol. 27, No 1, pp. 66-80.

Jacobs, C. 2005. On being an insider on the outside: new spaces for integrating academic literacies. Teaching in Higher Education, Vol.10, No.4, pp. 475-487.

Jackson, L., Meyer, W. and Parkinson, J. 2006. A study of the writing tasks and reading assigned to undergraduate science students at a South African University. English for Specific Purposes, Vol. 25, pp. 260-281.

Jubhari, R. 2009. Academic writing as discourse practice in Australian and Indonesian universities: A critical review, Educationist, Vol. 3 No.2, pp.67-81.

Jurecic, A. 2006. Is Teaching Writing Still Possible? New Jersey Writing Alliance, pp. 1-13. Available from:

http://www2.bergen.edu/njwa/NJWA_2006_materials_jurecic.pdf Accessed on 03 March 2011.

Kobayashi, H. \& Rinnert, C. 2002. High school student perceptions of first language literacy instruction: Implications for second language writing, Journal of Second Language Writing, Vol.11, pp. 91-116.

Krause, K. 2001. The university essay writing experience: A pathway for academic integration, Higher Education Research and Development, Vol.20, No.2, pp.147-168.

Lea, M.R. 2004. Academic Literacies: a pedagogy for course design. Studies in Higher Education, Vol. 29, No. 6, pp. 739-756.

Lea, M. R. and Street, B.V. 2006. The "Academic Literacies" Model: Theory and Applications. Theory into Practice, Vol. 45, No. 4, pp. 368-377.

Lillis, T. 2001. Student Writing: Access, Regulation, Desire. New York, Routledge.

Luna, C. 2002.Learning from diverse learners: (Re) writing academic literacies and learning disabilities in college. Journal of Adolescent and Adult Literacy, Vol.45 No.7, pp. 906-605. 
Maloney, W. H. 2003. Connecting the texts of their lives to academic literacy: Creating success for at-risk first year college students. Journal of Adolescent \& Adult Literacy, Vol. 46, No.8, pp. 664-673.

Mitchell, S. \& Evison, A. 2006. Exploiting the potential of writing of educational change at Queen Mary, University of London. In L. Ganobcsik-Williams (Ed) Teaching Academic Writing in UK Higher Education: Theories, Practices and Models, New York: Palgrave, Macmillan.

Moore, R.1998. How science educators construe student writing. In Angelil-Carter, S. (Ed.) Access to success: Literacy in academic contexts. Cape Town: University of Cape Town Press.

Moutlana, I.N. 2007. Challenges facing higher education: The problem of Academic Literacy, VC/Speeches/ North West University Workshop-17 September 2007, pp.1-15.

Munro, J. 2003. Fostering Literacy across the Curriculum. International Journal of Learning, Vol. 10, pp. 327-336.

Nightingale, P. 1988. Understanding processes and problems in student writing, Studies in Higher Education, Vol.13, No.3, pp. 263-283.

Niven, P.M. 2005. Exploring first year students' and their lecturers' constructions of what it means to read in the humanities discipline: a conflict of frames? South African Journal of Higher Education Vol.19, No. 4.pp. 777-789.

North, S. 2005. Different Values, Different skills: A Comparison of essay writing by students from arts and science background, Studies in Higher Education, Vol. 30, No.5 pp. 517-533.

Rose, D. 2004.Sequencing and pacing of the hidden curriculum: How indigenous children are left out of the chain? In J. Muller, A. Morais \& B. Davies (Eds.) Reading Bernstein, Researching Bernstein. London: Routledge Falmer.

Sanchez, D.M. and Paulson, E.J. 2008: Critical Language Awareness and Learners in College Transitional English. Teaching English in the two year College, Vol.36 No: 2.pp. 164-176.

Van Rensberg, W. and Lamberti, P. 2004. The language of learning and teaching. In Gravett, S. and Geyser, H.C. (Eds). Teaching and learning in higher education. Pretoria, van Schaik Publishers.

Van Schalkwyk, B. and van der Walt, E. 2009. Acquiring academic literacy: a case of first year extended degree programme students. Southern African Linguistics and Applied Language Studies, Vol. 27, No. 2, pp. 189-201.

Wingate, U. 2006. Doing away with the study skills, Teaching in Higher Education, Vol.11, No. 4, pp. 457-469.

Wood, P. 2013. Slowing down the process of time. Conference Proceedings of the Annual Postgraduate Research Conference held from 26-30 July at the University of Leicester, UK.

Yong, F.L. 2010. Attitudes toward academic writing of foundation students at an Australian-based university in Sarawak, European Journal of Social Sciences, Vol. 13. No.2, pp. 472-478.

Zamel, V. 1992. Writing One's Way into Reading, TESOL Quarterly, Vol. 26, No.3, pp 463-485. 
